\title{
Construction and Validation of Occupational Stress Scale for Public Prosecutors
}

\author{
Ahmed Bilal $^{1}$ and Syeda Shahida Batool ${ }^{2} *$
}

\begin{abstract}
Occupational stress has the adverse effects on personal and work-related life of workers. Public prosecutors experience specific stressors at work, but no scale has yet been designed to measure occupational stress among public prosecutors. The present study was carried out to construct and validate an indigenous Occupational Stress Scale for Public Prosecutors in Pakistan. An inductive approach was used for item generation. After ensuring the construct fidelity and content validity: the items of the scale were subjected to principal axis factoring, using a varimax rotation method on a sample of 416 public prosecutors and 32 items were retained in a well-defined 5 factor structure, which collectively accounted for 54.39 percent of the variance. Moreover, a confirmatory factor analysis on a sample of 350 public prosecutors was performed through AMOS modeling and the final scale consisted of 26 items was obtained. The relationship of scale with job satisfaction was found to be the negative $(r=-.30, p<.01)$ that determined its divergent validity. Furthermore, the relationship of the scale with Health and Safety Executive Management Standard Indicator Tool was found to be the positive $(r=.52$, $p<.01)$ that determined its convergent validity. The final scale is a promising measure with good items homogeneity, internal consistency and optimum validity.
\end{abstract}

Keywords: Occupational stress; Reliability; Validity; Public prosecutors; Scale development.

\section{Introduction}

Occupational stress pertains to the tasks of an individual at workplace, and has become widespread and prevails in the organizations irrespective of their categories (Ahmad \& Ahmad, 1992). It usually results from the responsibilities and pressures that are unexpected and mismatch with person's knowledge and skills leading towards the perceived inability to deal with such a situation. Occupational stress is assumed to increase in intensity when employees are not helped out by their senior colleagues or they feel little control over their work processes (WHO, 2020).

The major approaches and models of stress define and explain stress differently, as the transactional model of stress states that stress is the result of a transaction between a person and their surroundings (Lazarus \& Folkman, 1987). However, the appraisal of this person-environment transaction that

\footnotetext{
${ }^{1}$ Department of Psychology, Government College University, Lahore, Punjab, Pakistan.

${ }^{2}$ Department of Psychology, Government College University, Lahore, Punjab, Pakistan.
}

*)Corresponding Author.

Email: dr.shahidabatool@gcu.edu.pk 
offers a pathway of dealing with the stressor, highlights the whole process and experience (Lazarus et al., 2001). The effort-reward imbalance theory (ERI) portrays that the imbalance between a person's input (efforts) and the reward and opportunities he gets-can result in a stress or distress (Siegrist, 1996). The person-environment fit (PEF) theory suggests that when there is a misfit between an individual's abilities, skills, and resources and the demands of his work environment, the work-related stress arises (Caplan, 1987). The job demand-control (JDC) theory supports the view that a conflict between a person's job-related demands (psychological, cognitive, emotional, workload demands, etc.) and the job control (amount of control s/he has over her/his job (e.g., authority, decision-making power, and autonomy) can cause workrelated stress (Karasek, 1979).

Most of the models and empirical studies claim that occupational stress is associated with a variety of factors including workload issues, adapting to change, resources and support, and work-life balance (Singh et al., 2020). The factors including the stressful working conditions ; the lack of necessary skills to perform usual tasks ; uncertainty regarding the job role ; poor supportive management by superiors and not having adequate opportunities for career advancement define stress (Kaburi et al., 2019). Nawaz and Ashraf (2016), classified an occupational stress into four constructs (i.e., support at work, pressure at work, job satisfaction, and nature of job).

One major underlying cause of occupational stress (OS) is workplace violence for example; harassment, mobbing, ostracism, and stalking (Rasool et al., 2020).

Occupational stress has always been an important subject because of its effect on psychological well-being, burnout, work-life balance, and the various aspects of job performance. A higher degree of occupational stress relates with poorer mental status and hypertension in workers, and occupational stress may have an effect on job burn-out, hypertension and depression symptoms (Yong et al., 2020).

Empirical work on police officers, law enforcement workers, lawyers, prosecutors, and public defenders directs that every department has its own indicators of occupational stress. A study to assess occupational stress among police officers and its risk factors reveals that the major stressors in service operations were personal relationships outside work, injury risk, bureaucracy, tiredness, and lack of leisure for family and friends; and in service sector of organization; lack of personnel; lack of sources; inappropriate equipment; inappropriate distribution of responsibilities, and lack of meritocracy are the major stressors. Moreover, police officers working out of office were prone to more occupational stress than in-office police officers (Galanis et al., 2019). Moreto (2016), found that the law enforcement rangers were exposed to several task-related, internal, external, and occupation-related personal strains. In traffic police officers, the main influencing factors of job demand control and effort reward imbalance were education, monthly income level; work experience; marriage, and average weekly hours. However, gender and age 
also played the significant role in influencing effort reward imbalance related occupational stress (Rong et al., 2019).

However, these studies also found the role of demographics in stress for example, Welch (2018), concluded that stress was moderately higher among female public defenders than for male defenders. Moreover, the prevalence of stress-related psychopathology was found to be more in women (Savic, 2020). Women were more vulnerable to organizational and operational stressors in all operational service roles than men. However, men were more vulnerable to the organizational stressors in the interior department (Acquadro et al., 2015). An age also affects the perceived stress and emotional exhaustion for example, public defenders with age 60 and the above perceived lesser stress and lesser emotional exhaustion than the younger ones (Welch, 2018).

Public prosecutors have their unique job-related stressors that demand indepth exploration of nature and kind of their stress. Prosecutors ensure the social justice, but their role as an advocate is much deeper and complex. They are intensely dedicated to the outcomes of their cases and justice. They can assist in recognizing and correcting wrongful convictions, and also initiate policies to stay away from wrongful convictions in the first place (Bishop \& Osler, 2015).

Prosecutors are prone to high levels of role overload, and that overload leads to considerable strain. These conditions also have the several impacts upon the administration of justice (Gomme \& Hall, 1995). In addition to examining the causes and predictors of occupational stress in public prosecutors, its impact and outcomes also served as the basis of interest for many researches. A study attempting to explore the causes and consequences of job-related stress in prosecutors, and found that the organizational support, and job demands play the key roles in explaining the occupational stress of prosecutors. Job-related stressors did not directly lead to turnover intention, but indirectly through work-stress and job satisfaction (Na et al., 2018).

\subsection{Rationale and Objectives of the Study}

The previous studies have used a generic tool to measure stress in the different professions. An indigenous literature indicates that the multiple occupational stress scales had been developed in Pakistan for specific professions (e.g., for banking sector, medical doctors, school, and university teachers, etc.,), but there is no scale available that focuses to measure stress level and stress domains of public prosecutors. Ignoring the fact that public prosecutors have very different work set-up and job demands, which make their job-related stressors unique, it is common practice to measure their stress with the generic stress measuring tools. Measuring stress related to a specific job with a generic measure- can make our results biased and misleading that is why the present study was designed to fill the gap and develop the valid and reliable tool to measure occupational stress of public prosecutors in Pakistan in the different domains. 


\section{Methodology}

The valid and reliable occupational stress scale for public prosecutors (OSSPP) was developed in two independent studies: for the study 1, items of the scale were generated and factor structure of the scale was explored via exploratory factor analysis (EFA) and in the study 2, confirmatory factor analysis (CFA) was run and construct validity established in this manner.

\subsection{Study 1: Development of Occupational Stress Scale for Public Prosecutors (OSSPP)}

\subsubsection{Phase 1: Items Generation and Evaluation}

Initially, items pool was generated through a qualitative exploration that included semi-structured interviews of 12 public prosecutors ( 9 men and 3 women), working as 17 th and 18th grade officers with 3 to 15 years of service experience in the different districts of Punjab (e.g., Lahore, Faisalabad, Multan, Chiniot, Kasur, and Sheikhupura). Via thematic analysis, major themes (viz., Lack of Facilities; Structural Issues; Workload Pressures; Workplace Challenges; Interdepartmental Relationships; Personal Life and Health Issues; Financial Strain, and Administrative Issues) were extracted. A set of 49 items were generated.

The items were further, discussed and improved by taking experts' opinion in a group of experts (viz., a lecturer in psychology, an organizational psychologist; and 3 public prosecutors). Finally, we retained 41 items, and eight items were dropped due to redundancy, irrelevance, and ambiguity. In the pilot study, 4 out of 41 items were excluded due to non-normality and redundancy and 37 items were selected for factor structuring of the scale.

\subsubsection{Phase II: Factor Structuring of Scale (OSSPP)}

Phase II of the study 1 aimed to explore the factor structure and determine the psychometric properties of the scale.

2.1.2.1 Sample. Using a purposive sampling technique, a sample of 450 public prosecutors (395 men and 55 women) of grades 17th and 18th was selected from 10 cities of Punjab (Lahore, Okara, Kasur, Gujrat, Sargodha, Sahiwal, Narowal, Attock, Gujranwala, and Sialkot). Public prosecutors had been serving as ADPP and DDPP (assistant district public prosecutor and deputy district public prosecutor) for the last 3 to 15 years in the prosecution department.

2.1.2.2 Procedure. Public prosecutors were approached at their workplaces by the first author. The permission was taken from the public prosecutors prior to data collection. A questionnaire consisting of 37 items was distributed among the participants. Out of 450 participants, 416 completed the questionnaire, which were found an appropriate to be included in the analysis. In EFA, fourteen more cases were excluded because of some missing values in the data. All the assumptions given by Field (2005) were checked. 
2.1.2.2 Results. Exploratory factor analysis is used when researcher has a slight idea about the primary mechanism of the target issue, but is an unsure about how the variables will function with the each other. EFA helps to investigate the latent factors that can the best account for the differences and interrelationships among established variables (Henson \& Roberts, 2006). Data of 416 participants (370 men and 46 women) were subjected to EFA by using the varimax rotation method. Principal Axis Factor (PAF) yielded 5 factor solutions. The criterion of Kaiser (1960) was followed to retain items.

\section{Table 1}

Mean, Standard Deviation, Rotated Factor Loadings and Communalities for Occupational Stress Scale for Public Prosecutors $(N=416)$.

\begin{tabular}{|c|c|c|c|c|c|c|c|c|}
\hline \multicolumn{2}{|l|}{ Original items } & \multicolumn{7}{|c|}{ Factors } \\
\hline & $M$ & $S D$ & 1 & 2 & 3 & 4 & 5 & $h^{2}$ \\
\hline $\begin{array}{l}\text { 1. Due to non-availability of } \\
\text { lockers, the responsibility } \\
\text { falls on me to keep the files } \\
\text { of cases at a safe place. }\end{array}$ & 3.40 & 1.15 & .76 & .05 & .06 & .09 & .01 & $\begin{array}{l}.7 \\
4\end{array}$ \\
\hline $\begin{array}{l}\text { 2. We are deprived of fringe } \\
\text { benefits (vehicle and home } \\
\text { facilities). }\end{array}$ & 4.08 & .82 & .72 & .06 & -.01 & -.07 & -.05 & .68 \\
\hline $\begin{array}{l}\text { 3. Due to non-conducive office } \\
\text { environment, I have to take } \\
\text { work to home to complete } \\
\text { my office assignments. }\end{array}$ & 3.78 & $\begin{array}{c}1.1 \\
0\end{array}$ & .68 & .17 & .11 & -.05 & -.03 & .84 \\
\hline $\begin{array}{l}\text { 4. Inefficient procedures such } \\
\text { as excessive paperwork and } \\
\text { record keeping make my job } \\
\text { burdensome. }\end{array}$ & 3.83 & .99 & .62 & -.03 & .25 & .04 & .21 & .58 \\
\hline $\begin{array}{l}\text { 5. Unequal distribution of work } \\
\text { among prosecutors by heads } \\
\text { of districts is stressful. }\end{array}$ & 3.41 & $\begin{array}{c}1.1 \\
2\end{array}$ & .20 & .06 & .13 & -.01 & .02 & .42 \\
\hline $\begin{array}{l}\text { 6. There is no proper sitting } \\
\text { place in courts during trial. }\end{array}$ & 3.97 & .99 & .50 & -.06 & .26 & .09 & .20 & .47 \\
\hline $\begin{array}{l}\text { 7. There is limited access to } \\
\text { updated literature regarding } \\
\text { departmental laws, books } \\
\text { and amendments. }\end{array}$ & 4.36 & .65 & .46 & .02 & .29 & -.06 & .15 & .79 \\
\hline $\begin{array}{l}\text { 8. Congested office seating } \\
\text { causes discomfort. }\end{array}$ & 4.02 & $\begin{array}{c}1.1 \\
3\end{array}$ & .50 & .02 & .63 & -.19 & .19 & .95 \\
\hline 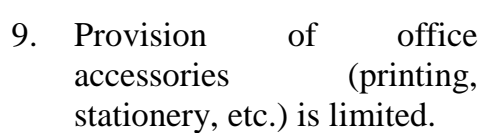 & 4.24 & .66 & .38 & .04 & -.08 & .02 & .22 & .53 \\
\hline $\begin{array}{l}\text { 10. There is lack of support } \\
\text { (clerical staff) for office } \\
\text { work. }\end{array}$ & 4.01 & .60 & .35 & -.08 & .20 & .09 & .16 & .36 \\
\hline 11. I do not have an independent & 3.89 & 1.6 & .32 & -.02 & .117 & .12 & .19 & .27 \\
\hline
\end{tabular}


office.

12. Private lawyers are not cooperative.

13. Public underestimates the services of public prosecutors.

14. It is always challenging to deal with police for a case.

15. I receive threats from accused.

16. I receive threats from complainants.

17. Private lawyers are hostile towards public prosecutors

18. Public prosecutors receive threats from private lawyers.

19. I have to take judges' negative and embarrassing criticism over my work even if I do not deserve it.

20. There is no recognition for good quality work.

21. There are less promotion opportunities in the department.

22. We have comparatively lower salaries than those on the same scales in other departments.

23. Disciplinary inquiries over minor issues cause stress.

24. Useless trainings are conducted for us.

25. There is no incentive for good quality work.

26. Due to workload pressures, I cannot perform my tasks effectively.

27. I am unable to do justice with family obligations due to job demands.

28. Less time for plenty of cases, makes my life stressful.

29. Due to office work, household duties are being ignored.

30. Office work has negative effect on my physical health.

31. Office work affects my mental health.

32. Outstation postings are stressful

$\begin{array}{lccccccc}3.26 & 1.05 & .16 & . \mathbf{8 1} & .03 & .12 & .06 & .93 \\ 3.09 & 1.15 & -.03 & .79 & .10 & .21 & .09 & .92 \\ 3.51 & 1.49 & .22 & . \mathbf{7 2} & -.12 & .22 & .29 & .92 \\ 2.84 & 1.11 & -.14 & . \mathbf{7 1} & .40 & .16 & -.13 & .92 \\ 2.44 & .84 & -.06 & . \mathbf{6 6} & .08 & -.09 & -.02 & .86 \\ 3.14 & 1.06 & .04 & . \mathbf{6 4} & -.02 & .05 & -.08 & .75 \\ 3.75 & .87 & .28 & . \mathbf{2 4} & .21 & .27 & -.10 & .76 \\ & & & & & & & \\ 3.40 & 1.1 & .48 & .36 & .45 & .08 & .24 & .89 \\ & 1 & & & & & & \\ 4.12 & .86 & .38 & -.19 & . \mathbf{3 3} & .14 & -.23 & .51 \\ 4.08 & .82 & .38 & .48 & .52 & -.04 & .14 & .85\end{array}$

$\begin{array}{lllllllll}4.63 & .58 & .45 & -.34 & \mathbf{5 0} & .38 & .24 & .94\end{array}$

$\begin{array}{lllllllll}4.07 & .84 & .27 & -.01 & \mathbf{3 2} & .07 & .16 & .36\end{array}$

$\begin{array}{lllllllll}3.31 & 1.23 & .13 & .11 & .29 & .04 & .04 & .50\end{array}$

$\begin{array}{lllllllll}4.20 & .80 & .38 & .25 & .49 & -52 & -.11 & .83\end{array}$

$\begin{array}{lllllllll}3.39 & 1.11 & .47 & .19 & .26 & .03 & .14 & .54\end{array}$

$\begin{array}{lllllllll}3.03 & .89 & .22 & .25 & .05 & \mathbf{8 9} & .04 & .99\end{array}$

$\begin{array}{lllllllll}3.03 & .89 & .23 & .25 & .05 & \mathbf{8 9} & .04 & .99\end{array}$

$\begin{array}{lllllllll}3.13 & .89 & -.16 & .20 & .31 & .73 & .33 & .95\end{array}$

$\begin{array}{lllllllll}3.10 & 1.03 & -.07 & .37 & .57 & \mathbf{. 5 1} & -.29 & .96\end{array}$

$\begin{array}{llllllllll}3.01 & 1.28 & .07 & .42 & .65 & .31 & -.31 & .96\end{array}$

$\begin{array}{lllllllll}4.44 & .97 & .34 & -.02 & .13 & .23 & .02 & .41\end{array}$ 
33. We are not allowed to use powers (conferred by law upon us) without pressure.

34. The department imposes ineffective policies on us.

35. Upgraded administrative policies are not communicated properly.

36. Undue excessive monitoring of our work by the department creates stress.

37. Administration does not pay attention to resolve our issues that occur during work.

$\begin{array}{lrcccc}\text { Eigenvalue } & 5.7 & 4.7 & 3.7 & 3.4 & 2.4 \\ \text { Alpha Reliability } & .91 & .83 & .86 & .69 & .87 \\ & & & & 9.2 & 6.5 \\ \text { \% of Variance } & 15.57 & 12.78 & 10.23 & 6 & 3\end{array}$

Table 1 shows five well- defined factors on the basis of scree plot, eigen values $>1.0$ and theoretical relevance. These factors were labelled on the basis of their similar content and theoretical support. Total 54.39 percent of the variance was accounted by these 5 factors. Five-point Likert type scale was used, with Strongly Disagree as 1, Disagree as 2, Neutral as 3, Agree as 4 and Strongly Agree as 5.

Table 2

Percentages of Variance Explained by All Factors $(N=416)$

\begin{tabular}{|c|c|c|c|}
\hline $\begin{array}{l}\text { Factor } \\
\text { no. }\end{array}$ & Factor Labels & Items & $\%$ of variance \\
\hline 1 & Lack of Facilities & $2,6,7,10,16,25,30,32,33,37$ & 15.57 \\
\hline 2 & $\begin{array}{l}\text { Interdepartmental } \\
\text { Challenges }\end{array}$ & $9,12,17,27,28,29,35$ & 12.78 \\
\hline 3 & Motivational Issues & $5,13,15,23,24,31$ & 10.23 \\
\hline 4 & $\begin{array}{l}\text { Personal Life and } \\
\text { Health Issues }\end{array}$ & $8,18,19,20,21$ & 9.27 \\
\hline 5 & Administrative Issues & $3,14,34,36$ & 6.53 \\
\hline
\end{tabular}

Table 2 represents the final scale emerged with 32 items in 5 well- defined factors. Five items are deleted due to low factor loadings and reliability $<.30$

\subsection{Study II: Validation of the Scale (OSSPP)}


The Study II was carried out in two phases to determine the psychometric properties of the scale, developed in the study I.

\subsubsection{Phase I: Confirmatory Factor Analysis and Reliability Analysis}

2.2.1.1 Sample. A purposive sampling technique was used to obtain a sample of 350 public prosecutors from 10 cities of Punjab (Lahore, Sheikhupura, Kasur, Faisalabad, Chiniot, Bahawalpur, Multan, Jehlum, Gujranwala, and Sialkot). The sample consisted of 306 male and 44 female public prosecutors with the inclusion criteria observed in the study 1.

2.2.1.2 Instrument and Procedure. The 32 items questionnaire of Occupational Stress Scale for Public Prosecutors (OSSPP), finalized after EFA was distributed among the participants at their workplaces, and they were given instructions to fill it honestly and independently.

2.2.1.3 Results. AMOS 21.0 was utilized to run CFA on the data. Out of 32 items, 26 items were retained and 6 items were deleted due to their low factor loadings.

Figure 1 indicates 26-items factor loadings and correlation between 5 subscales of the Occupational Stress Scale for Public Prosecutors. The factor loadings of all the retained items ranged from .31 to .74 on five factors: $\mathrm{LOF}=$ Lack of Facilities; IDC = Interdepartmental Challenges; $\mathrm{MI}=$ Motivational Issues $; \mathrm{PLHI}=$ Personal Life and Health Issues $; \mathrm{AI}=$ Administrative Issues. 


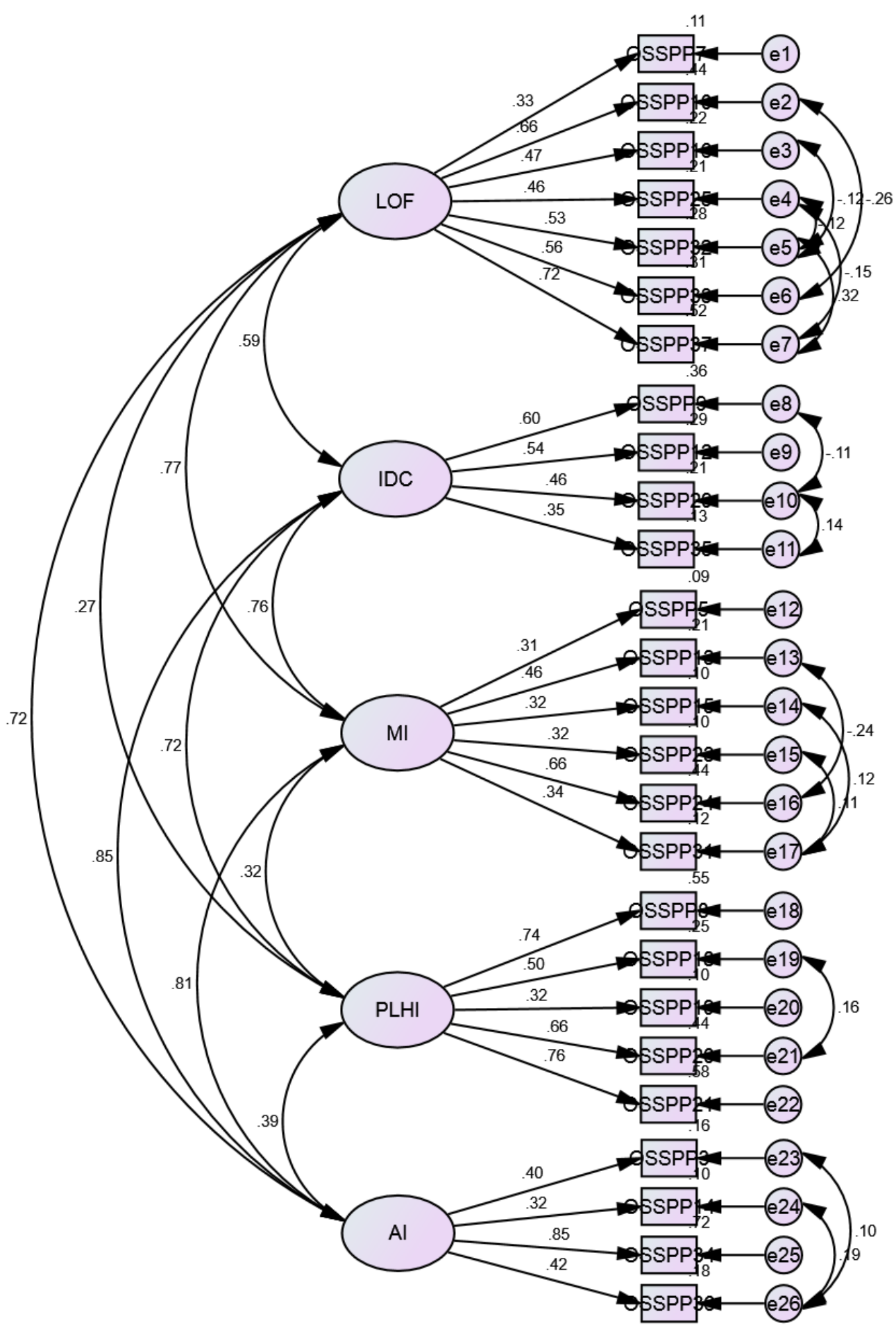

Figure 1 
Table 3

Model Fit Indices $(N=350)$

\begin{tabular}{llllllll}
\hline Models & $\chi 2$ & Df & $\chi 2 / \mathrm{df}$ & CFI & GFI & TLI & RMSEA \\
\hline Initial & 977.14 & 289 & 3.38 & .70 & .81 & .70 & .08 \\
Revised & 480.13 & 252 & 1.91 & .90 & .91 & .90 & .05 \\
\hline
\end{tabular}

Note . CFI $=$ conformity fit index; GFI $=$ Goodness of fit index; TLI $=$ Tucker

Lewis Index; RMSEA=root-mean- square error of approximation;

Table 3 explained model fit indices for the five-factor model. All of these indices exceed the satisfactory limit of $\chi 2 / \mathrm{df}<3$, CFI $>.90$, GFI $>.90$, TLI $>$ .90 , RMSEA $<0.08$, and SRMR $<0.05$ (Hu \& Bentler, 1999). The initial criteria for the item loading is $>.30$, the 32 -item model obtained through EFA was further examined in CFA, where 6 items were deleted due to low factor loading and overall factor structure showed good model fit. The final obtained model consists of 26 items, after adding modification indices for the fivefactor model, after considering Whittaker (2012), the statistical significance improved the model fit.

In order to find out the internal consistency of the total scale and subscales, reliability analysis was run on a normative sample $(\mathrm{N}=350)$, which indicate high internal consistency.

\section{Table 4}

Internal Consistency and Inter-correlations between Different Subscales of $\operatorname{OSSPP}(N=350)$

\begin{tabular}{|c|c|c|c|c|c|c|c|}
\hline Variable & 1 & 2 & 3 & 4 & 5 & 6 & $\alpha$ \\
\hline 1. OSSPP & - & & & & & & .84 \\
\hline 2. Lack of facilities & $.78 * *$ & - & & & & & .72 \\
\hline $\begin{array}{l}\text { 3. Interdepartmental } \\
\text { challenges }\end{array}$ & $.71 * *$ & $.40 * *$ & - & & & & .61 \\
\hline 4. Motivational issues & $.73 * *$ & $.54 * *$ & $.35 * *$ & - & & & .60 \\
\hline $\begin{array}{l}\text { 5. Personal life and health } \\
\text { issues }\end{array}$ & $.63 * *$ & $.22 * *$ & $.50 * *$ & $26 * *$ & - & & .75 \\
\hline 6. Administrative issues & $.71 * *$ & $.50 * *$ & $.43 * *$ & $.49 * *$ & $.28 * *$ & - & .63 \\
\hline
\end{tabular}

$* * *=p<.001, * *=p<.01$

Table 4 illuminates moderate to high positive correlations between the different subscales of OSSPP and total score of OSSPP. Values of Cronbach's alpha indicate that total scale and sub-scales have promising reliabilities. 


\subsubsection{Phase II: Divergent and Convergent Validity of the Scale (OSSPP)}

Phase II was aimed to determine the construct validity of OSSPP by determining its convergent and divergent validity. Divergent validity of the scale was determined by finding its correlation with Job Satisfaction Survey (Spector, 1985). The convergent validity was determined by finding its correlation with Health and Safety Executive Management Standards Indicator Tool (Cousins et al., 2004).

2.2.2.1 Sample. A sample of 350 public prosecutors was selected by following the criteria used in the previous phases of study 1 and study II, from the same cities of Pakistan. The sample consisted of 306 male and 44 female public prosecutors.

\subsubsection{Instruments.}

2.2.2.2.1 Occupational Stress Scale for Public Prosecutors (OSSPP). For the details see in a study 1 .

2.2.2.2.2 Job Satisfaction Survey (JSS). It is a 36-item scale developed by Spector in 1985. The scale comprises 9 subscales and uses 6-point Likert-type scale to record the responses of the participants. The overall reliability of the scale is reported to be $\alpha=.91$.

\subsection{Health and Safety Executive Management Standards Indicator Tool (HSEMS-IT). This scale was developed by Cousins et al. in 2004 and its psychometric were established by Edwards et al. in 2008. It is a 35-items self- report measure: a questionnaire commonly used to assess work-related stress risks at an organizational level. The scale comprises 7 subscales and uses 5- point Likert-type scale to record the responses of the participants. The overall reliability of the scale is reported to be $\alpha=.92$.}

2.2.2.3 Procedure. Public prosecutors were contacted and given a visit in their offices at their convenience for data collection. After obtaining their consent, prosecutors were briefed about the aim of the study, and were assured that their responses would remain confidential. They were also told that any participant could back out from the research any time. The 26 items OSSPP, 36 items JSS, and 35-items HSEMS self-report measures were administered on 350 public prosecutors of Punjab Province.

\subsubsection{Results.}

\section{Table 5}

Correlations between Occupational Stress Scale and Job Satisfaction Scale ( $N=350)$ 


\begin{tabular}{llllllll}
\hline Variables & 1 & 2 & 3 & 4 & 5 & 6 & 7 \\
\hline 1. JSS & - & & & & & & \\
2. OSSPP & $-.30^{* *}$ & - & & & & & \\
3. LOF & $-.28^{* *}$ & $.77^{* *}$ & - & & & & \\
4. IDC & $-.19^{* *}$ & $.70^{* *}$ & $.36^{* *}$ & - & & & \\
5. MI & $-.20^{* *}$ & $.73 * *$ & $.53^{* *}$ & $.34 * *$ & - & & \\
6. PLHI & $-.14^{* *}$ & $.63^{* *}$ & $.21^{* *}$ & $.50^{* *}$ & $.26^{* *}$ & - & \\
7. AI & $-.21 * *$ & $.70^{* *}$ & $.49^{* *}$ & $.43^{* *}$ & $.45^{* *}$ & $.28^{* *}$ & - \\
\hline$* * *=p<.001, * *=p<01$ & & & & &
\end{tabular}

Note. JSS: Job Satisfaction Scale; OSSPP: Occupational Stress Scale for Public Prosecutor; LOF: Lack of Facilities, IDC: Interdepartmental Challenges; MI: Motivational Issues, PLHI: Personal Life and Health Issues, AI: Administrative Issues.

The results in Table 5 indicate significantly moderate negative correlation between OSSPP and JSS $(r=-.30, p<.001)$. All the subscales of OSSPP also significantly and negatively correlate with JSS, which hereby establishes the divergent validity of OSSPP.

\section{Table 6}

Correlations between OSSPP and HSEMS $(N=350)$

\begin{tabular}{llllllll}
\hline Variables & 1 & 2 & 3 & 4 & 5 & 6 & 7 \\
\hline 1. HSEMS & - & & & & & & \\
2. OSSPP & $.52^{* *}$ & - & & & & & \\
3. LOF & $.30^{* *}$ & $.77^{* *}$ & - & & & & \\
4. IDC & $.43^{* *}$ & $.70^{* *}$ & $.36^{* *}$ & - & & & \\
5. MI & $.37^{* *}$ & $.73^{* *}$ & $.53^{* *}$ & $.34^{* *}$ & - & & \\
6. PLHI & $.40^{* *}$ & $.63^{* *}$ & $.21^{* *}$ & $.50^{* *}$ & $.26^{* *}$ & - & \\
7. AI & $.39^{* *}$ & $.70^{* *}$ & $.49^{* *}$ & $.43^{* *}$ & $.44^{* *}$ & $.28^{* *}$ & - \\
\hline
\end{tabular}

$* * *=p<.001, * *=p<.01$

Note. HSEMS-IT: Health and Safety Executive Management Standards Indicator Tool and rest of abbreviation have been explained under Table 5.

The results in Table 6 point out the significant positive correlation between OSSPP and HSEMS $(r=.52, \mathrm{p}<.001)$. All the subscales of OSSPP 
also significantly and positively correlate with HSEMS, which hereby support the convergent validity of OSSPP.

\section{Discussion}

Two inter-linked studies were designed to develop and validate a scale measuring occupational stress in the public persecutors. The scale construction processes included an inductive approach, and both EFA and CFA were run to decide the factor structure of the scale. The labels of five factors emerged after EFA (see Table 1) were decided on the basis of their content and their relevance to the overall construct.

Lack of Facilities (LOF) means the facilities or the physical resources such as congested office seating, non-conducive work environment ;limited office accessories and updated literature related to law, deprivation of fringe benefits; non-availability of proper cupboards with the proper locks and excessive paper work. Most of the public prosecutors were of the views that due to less departmental resources, their work got twofold; as they had to abide by the job description and were taking an unnecessary burden of working in the congested office space and dealing with limited office accessories. LOF appeared to create huge and the unnecessary hurdles that increased their work and was contributing to occupational stress. Lazarus and Folkman (1984), proposed stress to be the result of negative relationship between the demands made upon the individuals by their environment and the resources they appraise - can be brought into use to cope with such stressful situations.

The second factor is Interdepartmental Challenges (IDC) that covers bearing judges' negative and embarrassing criticism, dealing with hostility coming from the private lawyers, working in disordered environment and unnecessary delays in work created by police and threatening comments from the accused ones. Public prosecutors stated that they had to fight at an every end to keep their work done. They reported that they were taking every stakeholder's pressure (e.g., judiciary, private lawyer; accused, or complainant). Performance pressure has also been reported to be the most stressful factor that employees experience at their workplace in the previous studies (Chan et al., 2000).

The third factor is Motivational Issues (MI) which includes lower salaries as compared to other governmental officers on the same scale and working in the similar capacity, zero recognition for their quality work, workload pressures, no incentives, less promotion opportunities and disciplinary inquiries the over petty issues. Public prosecutors revealed that their good work was not being recognized and incentivized, so they lacked motivation to work from their heart. In addition to that, not only that they were oblivious of what they would be doing after their 15 years of service as public prosecutor, they had to stand an accountable for even very minor mistakes. This factor is in line with the effort-reward imbalance (Siegrist, 1996) model: one of most famous models of workplace stress. The model was initially proposed for 
people suffering from cardiovascular disease just like demand-control-support model (Siegrist, 1996). This model bears some features of transactional approach to stress at work, as it takes into account subjective perceptions of individuals about the stressful events that they experience. The key idea in effort-reward imbalance model is reciprocity. This reciprocal relation is between effort and reward, if efforts of employees are rewarded justifiably, they will feel the satisfied and motivated. On the other hand, if employees are not rewarded for their efforts it would lead towards stress (Peter \& Siegrist, 1999).

The factor 3 is also consistent with workplace stress model of "Job characteristics", proposed by Hackman and Oldham (1980) that emphasized on certain characteristics of job which gives rise to feelings of stress in employees. According to the authors, such characteristics are composed of variety of skills, task recognition, the importance of task; understanding of the task, independence; and feedback received by seniors. These features of an employee's job are critical for provoking positive or negative mental states and behavioral manifestations like; job satisfaction, motivation, and absenteeism.

The factors 4 is named as Personal Life and Health Issues (PLHI) that comprised less time given for plenty of cases, deterioration of their physical as well mental health, household duties being ignored due to the burden of office work and disturbance in family life. Public prosecutors reported that due to work burden, their household duties were being ignored and personal health was severely affected. The previous researches support the argument that stress causes many physiological and behavioral complications in people (Sabbarwal et al., 2017). People who endure a lot of stress pay less attention to their work and may therefore, be harming themselves and others in the organization. In the general, job stress reduces employee productivity. Working conditions play a key role in causing stress for employees, but cannot be ignored by individual factors (Cox, 2000). Russo and Vitaliano (1995), suggested that occurrence of workplace stressors right after family problems or simultaneous major life events and work place stressors have a strong impact on outcomes by reducing coping resources that people can utilize to deal with changes.

The factor 5 named as Administrative Issues (AI) was defined as undue excessive monitoring, ineffective policies; unnecessary departmental pressures and unannounced upgraded administrative policies. At the time of interviews, the public prosecutors were quite agitated and irritated over the fact that the department had made ineffective policies that increased their burden of work, and the upgraded administrative policies were not even properly communicated to them. The public prosecutors were also of the views that they were continuously and excessively monitored for their work and they could not use the powers (conferred by law upon them) without pressure. Pressure of the organizational authorities to maintain high-level performance along with multi-tasking had been found to be a stronger stressor for 
employees in the past (Cascio, 1995). The results are also in line with Townley (2000), survey in United Kingdom reporting that most of workers were dissatisfied with current working culture of their organizations where they had to work for longer hours, deal with an exhaustive workload as well meeting deadlines. This study also reported work related symptoms occurring because of these work demands which included headache, lose temperament and fatigue. The level of stress in employees increases when it is coupled with strict surveillance procedures, this trend has spread over most of the occupations that make working life more stressful (Humphrey, 1998).

Later on, CFA was run to validate the factor structure of a newly developed scale (OSSPP) on a separate sample of public prosecutors. The analysis fulfilled all the criteria to reveal an acceptable model fit to the data (see Table 3). All the items loaded independently on their respective factors.

Reliability analysis was also run to confirm the internal consistency of the scale and it was found very sound. The results indicate that occupational stress scale is highly reliable. The Cronbach's alpha coefficient of the overall scale and sub-scales fall in excellent range (see Table 4). The results suggest that items in occupational stress scale are internally consistent.

Convergent and divergent validity of newly developed s cale (OSSPP) was also established (see Table 5-6). Results indicted significant negative relation of OSSPP with job satisfaction and results are consistent with Yaacob and Long (2015) that indicate a significant negative relationship between job satisfaction and occupational stress. In a similar way, the results have been documented by Samuel et al. (2009), who explored the relationship of job stress, job satisfaction and psychological well-being with job satisfaction. The results of the study by Samuel et al. (2009), suggested the negative correlation of occupational stress with job satisfaction, and psychological well-being. The significant positive correlation of OSSPP with HSEMS ensures its convergent validity.

\subsection{Implications}

The scale can be applied for measuring the occupational stress of public prosecutors, working in Pakistan. Since there is dearth of literature on occupational stress in public prosecutors, the present study is a tremendous contribution as it can be used to assess the level of occupational stress of public prosecutors and interventions can be devised accordingly. The scale would help to devise occupational-stress management techniques in accordance with major job characteristics/demands of public prosecutors.

\subsection{Limitation and Suggestion}

Despite the significance of scale developed for measuring stress in public prosecutors, the newly developed scale is not free of limitations. The data were collected from one province of Pakistan (i.e., Punjab), so data from other provinces such as Khyber Pakhtunkhwa, Sindh, and Baluchistan should also be included in the future, to further validate OSSPP. We could not collect 
comparable data from female prosecutors due to lesser number of female prosecutors in the field, so we could not run analysis to assess gender differences in occupational stress among public prosecutors.

\section{Conclusion}

The objective of this study was to construct and validate a scale that measures occupational stress in public prosecutors. The results of both studies indicated that public prosecutors experience manifold stressors in the different domains of their job that lower their job satisfaction, and has detrimental impact on their life. An indigenously developed Occupational Stress Scale for Public Prosecutors appeared to be a valid and reliable, and we can use it in the future studies aimed to investigate occupational stress among public prosecutors.

\section{References}

Acquadro Maran, D., Varetto, A., Zedda, M., \& Ieraci, V. (2015). Occupational stress, anxiety and coping strategies in police officers. Occupational Medicine, 65(6), 466-473. https://doi.org/10.1093/occmed/kqv060

Ahmad, S., \& Ahmad, H. (1992). Role stress and work satisfaction: A study on middle managers. Indian Psychiatry Journal, 1(6), 110-115.

Bishop, J., \& Osler, M. (2015). Prosecutors and victims: why wrongful convictions matter. Journal of Criminal Law and Criminology, 105, 1031. https://ssrn.com/abstract $=2910781$

Caplan, R. D. (1987). Person-environment fit theory and organizations: Commensurate dimensions, time perspectives, and mechanisms'. Journal of Vocational Behavior 31(3), 248-267. https://doi.org/10.1016/0001-8791(87)90042-X

Cascio, W. F. (1995). Whither industrial and organizational psychology in a changing world of work. American Psychologist, 50(11), 928-939. https://doi.org/10.1037 /0003-066x.50.11.928

Chan, K. B., Lai, G., Ko, Y. C., \& Boey, K. W. (2000). Work stress among six professional groups: The Singapore experience. Social Science \& Medicine, 50(10), 1415-1432. https://doi.org/10.1016/s02779536(99)00397-4

Cousins, R., Mackay, C. J., Clarke, S. D., Kelly, C., Kelly, P. J., \& McCaig, R. H. (2004). 'Management Standards' work-related stress in the UK: Practical Development. Work \& Stress, 18(2), 113136. https://doi.org/10.1080/02678370410001734322

Cox, T., Griffiths, A., \& Rial-Gonzalez, E. (2000). Work-related stress. Luxembourg: Office for Official Publications of the European Communities. 
Edwards, J. A., Webster, S., Van Laar, D., \& Easton, S. (2008). Psychometric analysis of the UK Health and Safety Executive's Management Standards Work-related stress Indicator Tool. Work \& Stress, 22(2), 96-107. https://doi.org/10.1080/02678370802166599

Field, A. (2005). Discovering statistics using SPSS . London: Sage Publications Ltd.

Galanis, P., Fragkou, D., Kaitelidou, D., Kalokairinou, A., \& Katsoulas, T. A. (2019). Risk factors for occupational stress among Greek police officers. Policing: An International Journal, 42(4), 506-519. https://doi.org/10.1108/PIJPSM-09-2018-0131

Gomme, I. M., \& Hall, M. P. (1995). Prosecutors at work: Role overload and strain. Journal of Criminal Justice, 23(2), 191-200. https://doi.org/10.1016/0047-2352(95)00006-C

Hackman, J. R., Hackman, R. J., \& Oldham, G. R. (1980). Work redesign, reading (pp. 225-330). MA: Addison-Wesley. https://doi.org/10.1177/105960118200700110

Henson, R.K., \& Roberts, J. K. (2006). Use of exploratory factor analysis in published research: Common errors and some comment on improved practice. Educational and Psychological Measurement, 66(3), 393-416. https://doi.org/10.1177/ 0013164405282485

Hu, L. T., \& Bentler, P. M. (1999). Cutoff criteria for fit indexes in covariance structure analysis: Conventional criteria versus new alternatives. Structural Equation Modeling: A Multidisciplinary Journal 6(1), 1-55. https://doi.org /10.1080/10705519909540118

Humphrey, J.H. (1998). Job Stress. https://doi.org/10.1002/(SICI)1099 1700(199807) 14:3<203: AID-SMI794>3.0.CO;2-F

Kaburi, B. B., Bio, F. Y., Kubio, C., Ameme, D. K., Kenu, E., Sackey, S. O., \& Afari, E. A. (2019). Psychological working conditions and predictors of occupational stress among nurses, Salaga Government Hospital, Ghana, 2016. The Pan African Medical Journal, 33. https://doi.org/10.11604/pamj.2019.33.320.16147

Kaiser, H. F. (1960). The application of electronic computers to factor analysis. Educational and Psychological Measurement, 20, 141-151. http://doi.org/10.1177/001316446002000116

Karasek, R. A. (1979). Job demands, job decision latitude, and mental strain: Implications for job redesign. Administrative Science Quarterly, 24(2), 285-308. https://doi.org/10.2307/2392498

Lazarus, R. S., Cohen-Charash, Y., Payne, R., \& Cooper, C. (2001). Discrete emotions in organizational life. Emotions at Work: Theory, Research, and Applications for Management 4584.https://books.google.com.pk/books?hl=en\&lr=\&id= a0azIPHoj6QC\&oi=fnd\&pg=PA45\&dq=Lazarus, + R.+S.,+CohenCharash,+Y.,+Payne,+R.,+and+Cooper,+C.+(2001) 
Lazarus, R. S. and Folkman, S. (1987) 'Transactional Theory and Research on Emotions and Coping'. European Journal of Personality, 1(3), 141169. https:// doi.org/10.1002/per.2410010304

Lazarus, R. S., \& Folkman, S. (1984). Stress appraisal and coping. Retrieved from: www.springerpub.com/stress-appraisal-and-coping.html

Moreto, W. D. (2016). Occupational stress among law enforcement rangers: Insights from Uganda. Oryx, 50(4), 646654. https://doi.org/10.1017/S0030605315000356

Na, C., Choo, T., \& Klingfuss, J. A. (2018). The Causes and Consequences of Job-Related Stress among Prosecutors. American Journal of Criminal Justice, 43(2), 329-353. https://doi.org/10.1007/s12103-0179396-4

Nawaz, A., \& Ashraf, M. (2016). The Impact of Occupational Stress on University Employees' Personality. Journal of Education and Educational Development, 3(2),

179-202. http://dx.doi.org/10.22555/joeed.v3i2.1041

Peter, R., \& Siegrist, J. (1999). Chronic psychosocial stress at work and cardiovascular disease. International Journal of Law and Psychiatry, 22(5-6), 441-449. https://doi.org/10.1016/s01602527(99)00020-5

Rasool, F. S., Wang, M., Zhang, Y. \& Samma, M. (2020). Sustainable work performance: the roles of workplace violence and occupational stress. International Journal of Environmental Research and Public Health, 17(912). https://doi.org/10.3390/ijerph17030912

Rong, Y., Guo, K. R., Yin, H. F., Wu, Y. F., Li, S., \& Sun, D. Y. (2019). Evaluating the level of occupational stress and its influence factors among traffic police in a district in Shanghai. Chinese Journal of Industrial Hygiene and Occupational Diseases,37(5), 352356. https://doi.org/10.3760/cma.j.issn.1001-9391. 2019.05.007

Russo, J., \& Vitaliano, P. P. (1995). Life events as correlates of burden in spouse caregivers of persons with Alzheimer's disease. Experimental Aging Research, 21(3), 273-294. https://doi.org/10.1080/03610739508253985

Sabbarwal, S., Singh, M. M., \& Amiri, M. (2017). Occupational stress on employees in information technology organizations. Asian journal of social sciences \& humanities, 6(3), 104-110. http://www.ajssh.leenaluna.co.jp/AJSSHPDFs/ Vol.6(3)/AJSSH2017(6.3-12).pdf

Samuel, M.O., Osinow, H.O., \& Chipunza, C. (2009). The relationship between bank distress, job satisfaction, perceived stress, and psychological well-being of employees and depositors in Nigeria's banking sector. African Journal of Business Management, 3(11), 624632. Retrieved from http://www .academicjournals. org/journal/ AJBM/article-full-text-pdf/75F50F818477

Savic, I. (2020). MRS Shows Regionally Increased Glutamate Levels among Patients with Exhaustion Syndrome Due to Occupational 
Stress. Cerebral

Cortex, 30(6),

3759-3770. https://doi.org/10.1093/cercor/bhz340

Siegrist, J. (1996). Adverse health effects of high-effort/low-reward conditions. Journal of Occupational Health Psychology, 1(1), 27-41. https://doi.org/10.1037/1076-8998.1.1.27

Singh, C., Cross, W., Munro, I., \& Jackson, D. (2020). Occupational stress facing nurse academics-A mixed-methods systematic review. Journal of Clinical Nursing, 29(5-6), 720-735. https://doi.org/10.1111/jocn.15150

Spector, P. E. (1985). Measurement of human service staff satisfaction: Development of the Job Satisfaction Survey. American journal of community psychology, 13(6), 693-713. https://doi.org/10.1007/BF00929796

Townley, G. (2000). Long hours culture causing economy to suffer. Management Accounting, 78(6), 3-5. https://www.highbeam.com/doc/1G1-63059951.html

Welch, T. L. (2018). The sources and extent of public defender occupational stress (Doctoral dissertation, Nova Southeastern University). https://search.proquest.com/docview/2085349697 accountid=135034

World Health Organization. (2020, October 19). Occupational health: Stress at the workplace. World Health Organization. https://www.who.int/newsroom/q-a-detail/ccupational-health-stress-at-the-workplace

Yaacob, M., \& Long, C. S. (2015). Role of occupational stress on job satisfaction. Mediterranean Journal of Social Sciences, 6(2 S1), 81. https://doi.org/10.5901/mjss.2015.v6n2s1p81

Yong, X., Gao, X., Zhang, Z., Ge, H., Sun, X., Ma, X., \& Liu, J. (2020). Associations of occupational stress with job burn-out, depression and hypertension in coal miners of Xinjiang, China: a cross-sectional study. BMJ open, 10(7), e036087. http://dx.doi.org/10.1136/bmjopen2019-036087 